\title{
SUGARS AND ALCOHOLIC BYPRODUCTS FROM HENEQUEN (Agave fourcroydes) AS INFLUENCED BY PLANT AGE AND CLIMATE
}

\section{AZÚCARES Y SUBPRODUCTOS ALCOHÓLICOS DE HENEQUÉN (Agave fourcroydes) EN FUNCIÓN DE LA EDAD DE LA PLANTA Y EL CLIMA}

\author{
Luis A. Rendón-Salcido², Patricia Colunga-GarcíaMarín, Luis F. Barahona-Pérez ${ }^{1}$, \\ Eulogio Pimienta-Barrios ${ }^{2}$, Abdo Magdub-Méndez ${ }^{1}$ y Alfonso Larqué-Saavedra ${ }^{*}$
}

${ }^{1}$ Centro de Investigación Científica de Yucatán. Calle 43 No. 130. Col Chuburná de Hidalgo. 97200, Mérida, Yucatán. México. Phone: (999) 942-8330, Fax (999) 981-3900. ${ }^{2}$ Centro Universitario de Ciencias Biológicas y Agropecuarias, Universidad de Guadalajara. Carr. Km. 15.5 Guadalajara-Nogales. Predio las Agujas, Mpio. de Zapopan, Jalisco, México..

* Corresponding author (larque@cicy.mx)

\section{SUMMARY}

Henequen (Agave fourcroydes Lem.) is a well known fiber producing plant cultivated in the Yucatán peninsula in México. Recent studies revealed that the stem locally known as "piña" is a reservoir of non structural carbohydrates, which may be fermented to produce an alcoholic spirit similar to mezcal and tequila. In this work we determined the effect of plant age and climatic conditions through the year on sugars and alcohol production. "Piñas" from 5, $8,15,18$ and 19 year-old plants were harvested in the spring and autumn dry seasons, as well as in the rainy season of one single year. "Piñas" fresh weight varied from 5.2 to $6.7 \mathrm{~kg}$. Harvested "piñas" were cut into small pieces and cooked, followed by pressing to extract their juice; then the juice was fermented with Kluyveromyces marxianus native yeast isolated from henequen, and distilled to obtain two alcoholic products: "ordinary" (monodistilled) and "white" (bidistilled). Results showed that 19 year-old plants yielded the highest volume of ordinary alcohol production $(159 \mathrm{~mL}$ per liter of juice). "Piñas" harvested in the dry spring season produced greater quantities of "ordinary" alcohol than those harvested during the dry autumn and in the rainy seasons.

Index words: Agave fourcroydes, "piña", sugars, alcohol.

\section{RESUMEN}

El henequén (Agave fourcroydes Lem.) es una conocida planta productora de fibra cultivada en la península de Yucatán en México. Estudios recientes revelaron que el tallo localmente conocido como "piña" es una reserva de hidratos de carbono no estructurales que puede ser fermentado para producir un alcohol similar al tequila y al mezcal. En este trabajo se determinó el efecto de la edad de la planta y las condiciones climáticas a lo largo del año en el contenido de azúcares y producción de alcohol. "Piñas" de plantas de 5, 8, 15, 18 y 19 años de edad, fueron cosechadas en la estación seca de la primavera, en las estaciones de lluvias del verano y la temprana estación seca del otoño, de un año. El peso fresco de las "piñas" varió de 5.2 a $6.7 \mathrm{~kg}$. Las "piñas" cosechadas se cortaron en pequeños trozos y se cocieron, y después se presionaron para extraer su jugo; el jugo resultante se fermentó con Kluyveromyces marxianus, una levadura nativa aislada del henequén, y se destiló para obtener dos productos alcohólicos: "ordinario" (monodestilado) y "blanco" (bidestilado). Los resultados mostraron que las plantas de rendimiento más alto son las de 19 años de edad, en cuanto a volumen de producción de alcohol ordinario (159 $\mathrm{mL}$ por litro de jugo). Las "piñas" cosechadas en la estación seca de la primavera del año produjeron mayores cantidades de alcohol ordinario que las cosechadas durante la estación lluviosa del verano y que las de sequía temprana del otoño.

Palabras clave: Agave fourcroydes, piña, azúcares, alcohol.

\section{INTRODUCTION}

Henequen (Agave fourcroydes Lem.) is a well known fiber producing agave that grows in the Yucatán peninsula in México. It thrives in shallow infertile soil conditions and its leaves are harvested for fiber production. Leaf harvest usually starts four years after planting and continues over a period of 20 years (Guerrero and Dzib, 1983), after which leaf size begins to decrease as vegetative growth declines and the plant gets ready for flower production. Regularly, a great proportion of the carbohydrates produced by the leaves are allocated to fiber formation following a metabolic pathway not fully described yet, although some of the carbohydrates are stored in the stem. Metabolism translocation and accumulation of carbohydrates in henequen has not been widely studied to date.

Data from other agave species have shown that carbohydrates accumulated in the stem can be hydrolyzed and fermented to produce spirits such as tequila and mezcal (Tello-Balderas and García-Moya, 1985; Cedeño and Alvarez-Jacobs, 2000; Ramales-Osorio and Barragán- 
Rámirez, 2002). The henequen juice obtained from the leaves usually varies from 10.2 to $11.5^{\circ} \mathrm{Brix}$, containing $64 \mathrm{~g} \mathrm{~L}^{-1}$ of carbohydrates of which $25 \mathrm{~g} \mathrm{~L}^{-1}$ are reducing sugars mostly fructose and glucose, and sucrose as a non reducing sugar (Ayora-Cámara, 1986; Barahona-Pérez, 1987, Personal comm. ${ }^{1}$ ). On the other hand, the agave stem (locally named "piña") is an important reservoir of non structural sugars, such as inulin (Aspinall and Gupta, 1959; Wang and Nobel, 1998; Cedeño and AlvarezJacobs, 2000; López et al., 2003; Gómez-Ayala et al., 2004). When hydrolyzed these polymers yield mainly fructose, glucose and sucrose, which represent between 24 to $27 \%$ of the total carbohydrates content. The juice obtained from the henequen "piña" varies from 9 to 14 ${ }^{\circ}$ Brix.

Carbohydrates are produced via photosynthesis, and seasonal variations in climatic factors affect the net carbon gain in photosynthetic organs, as well as the movement of such photoassimilates to storage organs of economic importance (Nobel et al., 1998; Pimienta-Barrios et al., 2001). For instance, net $\mathrm{CO}_{2}$ uptake in Agave tequilana is severely reduced by temperatures over $35{ }^{\circ} \mathrm{C}$, while fresh day/night temperatures of $24 / 14{ }^{\circ} \mathrm{C}$ increased substantially both the net $\mathrm{CO}_{2}$ uptake and the accumulation of sugars in the stem (Nobel et al., 1998). Fresh climates increase sugars production in agaves growing under optimal soil moisture condition (Pimienta-Barrios et al., 2001). Early ecophysiological studies on Agave fourcroydes have shown that its daily net $\mathrm{CO}_{2}$ assimilation rate varies from 250 to $350 \mathrm{mmol} \mathrm{m}^{-2} \mathrm{~d}^{-1}$ under photosynthetic photon fluxes oscillating from 10 to $20 \mathrm{~mol} \mathrm{~m}^{-2} \mathrm{~d}^{-1}$ and day/night temperatures of $30 / 20{ }^{\circ} \mathrm{C}$ (Nobel, 1985).

Recent work done in our lab demonstrated that spirits can be obtained from the henequen "piñas", as it happens in other wild and cultivated agaves (Nobel, 1994), in addition to leaf fibers, thus increasing their agronomical value. However, the effects of climate on both alcohol and sugars production have not been studied. Therefore, the aim of this study was to determine the effects of plant age and seasonal climatic variations on the carbohydrates accumulation in the "piñas" of $A$. fourcroydes, and their subsequent conversion to alcohol. We postulated that the sugar content in the stem will be affected by climate and plant age, so that fresh seasonal temperatures will promote carbon gain production in aged plants, and consequently the accumulation of sugars in their stems.

\footnotetext{
${ }^{1}$ Barahona P L F (1987) Determinación de los azúcares presentes en el jugo de henequén (Agave fourcroydes) y su variación en el proceso de fermentación. Tesis de licenciatura de Ingeniero Industrial en Química. Instituto Tecnológico de Mérida. Mérida, Yucatán, México. 90 p.
}

\section{MATERIALS AND METHODS}

A henequen plantation located in San Antonio Temax, Motul, Yucatán, México was selected for the present study. The plot is located 8 masl where plants thrive on a stony rendzines and litosol soil slightly alkaline with $\mathrm{pH}$ between 7.3 to 8 (Duch, 1988; Duch, 1991). Climatological data for this site, from 1961 to 2004, were studied to define the harvest periods for the present study. The harvest periods selected were: 1) November-December (autumn dry season), 2) March-April (spring dry season), and 3) July-August (summer rainy season). A selection of $5,8,15,18$ and 19 year-old henequen plants was available in the plantation; therefore groups of 15 plants of each age were marked for subsequent work. A fully randomized experimental design was used; the factorial levels were five plant ages and three climatic periods, with three replications. The means test used was DMS $(\mathrm{P}<0.05)$. Data were analyzed using the Statgraphic 5.1 software.

Three plants were harvested during each climatic period by removing their leaves. The "piñas" fresh weight and axial length were recorded; thereafter, they were cut into pieces and cooked in an autoclave at $1 \mathrm{~kg} \mathrm{~cm}^{-2}$ pressure for $4 \mathrm{~h}$. The cooked "piñas" were pressed to collect their juice, which was adjusted with water to $12{ }^{\circ}$ Brix for subsequent fermentation.

Ammonium sulphate $\left(\mathrm{NH}_{4}\right)_{2} \mathrm{SO}_{4}$ at $1.5 \mathrm{~g} \mathrm{~L}^{-1}$ of juice was added to the juice as a nitrogen source and maintained at $30 \pm 2{ }^{\circ} \mathrm{C}$ in darkness, as suggested by our own patent (CICY, 2004). Once the temperature was reached, $100 \mathrm{~mL} \mathrm{~L}^{-1}\left(3.5 \times 10^{7}\right.$ yeasts $\left.\mathrm{mL}^{-1}\right)$ of the CICY KI (Kluyveromyces marxianus) yeast were added for fermenting the juice. After a fermentation period of $48-72 \mathrm{~h}$, an initial distillation was carried out at temperatures ranging from 65 to $98{ }^{\circ} \mathrm{C}$; the resulting alcohol was denominated "ordinary". This product was then subjected to a second distillation at temperatures between 75 and $85{ }^{\circ} \mathrm{C}$ and this alcohol was named "white".

Throughout the process total soluble solids (TSS) of the soluble solution were recorded using a Westover RHB32 refractometer. Reducing sugars were estimated in the cooked juice using the 3, 4-dinitrosalicylic acid (DNS) method reported by Sumner (1921) and modified by Castillo (1992; Personal comm. ${ }^{2}$ ), as follows: $1.5 \mathrm{~mL}$ of

\footnotetext{
${ }^{2}$ Castillo V A (1992) Comparación de diferentes fuentes de nutrientes para el crecimiento y fermentación de Saccharomyces cerevisiae en melaza de caña. Tesis de Licenciatura de Químico Farmacobiólogo. Facultad de Ciencias Químicas. Universidad de Guadalajara. Guadalajara, Jalisco, México. pp:1-42.
} 
DNS were added to samples of $0.5 \mathrm{~mL}$ of juice, and placed in a water bath until boiling for $15 \mathrm{~min}$, and afterwards left to reach room temperature. Eight milliliters of distilled water were added and read at $550 \mathrm{~nm}$ in a spectrophotometer Barnstead SP-830. Each determination was done on three replicates.

The ethanol present in the first and second distilled products was estimated using the potassium dichromate assay by Williams (1950) adapted by Castillo (1992, Op. cited) as follows: $2 \mathrm{~mL}$ of potassium dichromate solution were added to samples of $1 \mathrm{~mL}$ of distilled product, mixed and left to rest for $10 \mathrm{~min}$; then $5 \mathrm{~mL}$ of distilled water were added to each sample and read at $585 \mathrm{~nm}$. Each determination was done in three replicates.

\section{RESULTS AND DISCUSSION}

\section{"Piña" fresh weight and juice production}

"Piña" fresh weight varied according to age from 5.2 to $6.7 \mathrm{~kg}$ (Table 1), and across seasons it varied from 5.8 to $6.3 \mathrm{~kg} /$ piña (Table 2). No statistical differences were observed between plant ages nor in stem fresh weight across the seasons.

Table 1. Fresh weight (FW) and juice volume collected from henequen cooked "piñas" harvested at different ages. Yucatán, México. ( $\mathbf{n}=\mathbf{9} \pm$ standard deviation).

\begin{tabular}{lcll}
\hline $\begin{array}{l}\text { Age } \\
\text { (years) }\end{array}$ & $\begin{array}{c}\text { Fresh weight } \\
(\mathrm{kg})\end{array}$ & $\begin{array}{l}\text { Juice yield } \\
\text { (L/"piña") }\end{array}$ & Ratio FW/Juice \\
\hline 5 & $6.77 \pm 0.53 \mathrm{a}$ & $3.09 \pm 0.37 \mathrm{a}$ & $2.05 \pm 0.27 \mathrm{a}$ \\
8 & $6.13 \pm 0.44 \mathrm{a}$ & $3.01 \pm 0.30 \mathrm{a}$ & $1.69 \pm 0.14 \mathrm{a}$ \\
15 & $5.55 \pm 0.63 \mathrm{a}$ & $2.55 \pm 0.36 \mathrm{ab}$ & $2.59 \pm 0.30 \mathrm{a}$ \\
18 & $5.29 \pm 0.69 \mathrm{a}$ & $1.99 \pm 0.27 \mathrm{~b}$ & $3.00 \pm 0.48 \mathrm{a}$ \\
19 & $6.33 \pm 0.67 \mathrm{a}$ & $2.62 \pm 0.46 \mathrm{ab}$ & $3.99 \pm 1.84 \mathrm{a}$ \\
\hline
\end{tabular}

Means with the same letters in a column are statistically equal $(\mathrm{P} \leq$ $0.05)$.

Table 2. Fresh weight (FW) and volume of juice from henequen cooked "piñas" harvested in different climatic. Yucatán, México. (n=9 \pm standard deviation).

\begin{tabular}{lccc}
\hline $\begin{array}{l}\text { Climatic } \\
\text { conditions }\end{array}$ & $\begin{array}{c}\text { Fresh weight } \\
(\mathrm{kg})\end{array}$ & $\begin{array}{c}\text { Juice yield } \\
(\mathrm{L} / \text { "piña") }\end{array}$ & Ratio FW/Juice \\
\hline $\begin{array}{l}\text { Spring dry } \\
\text { period }\end{array}$ & $5.87 \pm 0.56 \mathrm{a}$ & $2.61 \pm 0.26 \mathrm{a}$ & $2.54 \pm 0.33 \mathrm{ab}$ \\
$\begin{array}{l}\text { Summer } \\
\text { rainy period } \\
\text { Autumn dry } \\
\text { period }\end{array}$ & $6.32 \pm 0.46 \mathrm{a}$ & $3.42 \pm 0.22 \mathrm{a}$ & $1.73 \pm 0.12 \mathrm{~b}$ \\
$\begin{array}{l}\text { Means with the same letters in a column are statistically equal }(\mathrm{P} \leq \\
\text { 0.05). }\end{array}$ &
\end{tabular}

\section{Volume of the juice}

The juice volume obtained from cooked "piñas" of different ages showed significant differences (Table 1).
"Piñas" 5 to 8 years-old produced $3.0 \mathrm{~L} /$ piña, while 15 to 19 year-old "piñas" showed a reduction in juice content; this reduction varied from 15.3 to $33.9 \%$ compared to the youngest "piñas". The harvest time also affected the final volume of juice collected from the cooked "piñas"; "piñas" collected in the dry spring period yielded $2.6 \mathrm{~L} /$ piña, while in the summer rainy period the volume of juice increased over $30.7 \%$ and diminished to $15.3 \%$ in the autumn dry season, with respect to the spring dry season (Table 2).

\section{Total soluble solutes content $\left({ }^{\circ} \mathrm{Brix}\right)$}

Plant age had a significant effect on the total soluble solids content in the "piñas" of henequen, since values varied from $11.7^{\circ}$ Brix in 8 year-old plants to 15.2 in 19 year-old plants. The highest soluble solutes content was recorded in those uncooked "piñas" harvested during the spring dry season with values of $17.4{ }^{\circ}$ Brix, and the lowest values $\left(9.7^{\circ} \mathrm{Brix}\right)$ were recorded in "piñas" collected in the autumn rainy season (Table 3 ). In the cooked juice the soluble solutes also varied significantly through plant ages (Table 4$)$; the highest values $\left(16.1^{\circ}\right.$ Brix ) were observed in 19 year-old "piñas" and the lowest in those from the 5, 8, 15 and 18 year-old plants, which had 18.5 to $29.1 \%$ less than the 19 year-old "piñas". The climatic conditions prior to harvesting also had a significant effect on the soluble solutes content of the cooked "piña" juice. The juice from the spring dry season had values of 16.5 ${ }^{\circ}$ Brix, which decreased by $30 \%$ in the summer rainy season and by $33.8 \%$ in the early autumn dry season. These data show that the highest TSS increased with age (up to 19 year-old plants), and are also increased by dry conditions.

Table 3. Total soluble solids content in uncooked henequen "piñas" harvested at different ages and climatic conditions. Yucatán, México. $(\mathbf{n}=9 \pm$ standard deviation $)$.

\begin{tabular}{|c|c|c|c|}
\hline $\begin{array}{l}\text { Plant age } \\
\text { (years) }\end{array}$ & $\begin{array}{c}\text { TSS } \\
\left({ }^{\circ} \text { Brix }\right)\end{array}$ & Climatic season & $\begin{array}{c}\text { TSS } \\
\left({ }^{\circ} \text { Brix }\right)\end{array}$ \\
\hline 5 & $12.54 \pm 0.93 \mathrm{bc}$ & \multirow{4}{*}{$\begin{array}{l}\text { Spring dry season } \\
\text { Summer rainy } \\
\text { season } \\
\text { Autumn rainy } \\
\text { season }\end{array}$} & $17.40 \pm 0.71 \mathrm{a}$ \\
\hline 8 & $11.79 \pm 1.53 \mathrm{c}$ & & $12.86 \pm 0.80 b$ \\
\hline 15 & $13.00 \pm 0.96 \mathrm{bc}$ & & $9.76 \pm 0.57 \mathrm{c}$ \\
\hline $\begin{array}{l}18 \\
19 \\
\end{array}$ & $\begin{array}{l}14.10 \pm 1.29 \mathrm{ab} \\
15.27 \pm 1.93 \mathrm{a}\end{array}$ & & \\
\hline
\end{tabular}

\section{Reducing sugars content}

Their content in the juice of cooked "piñas" varied with plant age, since "piñas" from 19, 18 and 5 years-old plants had the highest values (107.3 to $94.6 \mathrm{~g} \mathrm{~L}^{-1}$ ) 
compared to the 8 and 15 years-old "piñas" which had 21 to $35 \%$ lesser content (Table 4). The reducing sugars were also affected by the prevailing climatic conditions because their highest content was found during the dry spring period with $112 \mathrm{~g} \mathrm{~L}^{-1}$, whereas in the summer rainy season their content became diminished by $30 \%$ and by $32 \%$ in the autumn dry season.

Table 4. Total soluble solids and reducing sugars of henequen juice obtained from cooked "piñas" harvested at different ages and climatic seasons. Yucatán, México. ( $(\mathbf{m}=9 \pm$ standard deviation).

\begin{tabular}{lcc}
\hline Conditions & $\begin{array}{c}\text { TSS } \\
\left({ }^{\circ} \text { Brix }\right)\end{array}$ & $\begin{array}{c}\text { Reducing sugars } \\
\left(\mathrm{g} \mathrm{L}^{-1}\right)\end{array}$ \\
\hline Plant age (year) & & \\
5 & $11.91 \pm 0.97 \mathrm{~b}$ & $94.66 \pm 12.3 \mathrm{a}$ \\
8 & $11.45 \pm 1.05 \mathrm{~b}$ & $69.88 \pm 4.60 \mathrm{~b}$ \\
15 & $12.54 \pm 0.78 \mathrm{~b}$ & $75.14 \pm 5.91 \mathrm{~b}$ \\
18 & $13.15 \pm 1.17 \mathrm{~b}$ & $95.46 \pm 10.90 \mathrm{a}$ \\
19 & $16.15 \pm 1.24 \mathrm{a}$ & $107.31 \pm 11.55 \mathrm{a}$ \\
Climatic condition & & \\
Spring dry season & $16.55 \pm 0.69 \mathrm{a}$ & $111.84 \pm 9.30 \mathrm{a}$ \\
Summer rainy season & $11.61 \pm 0.57 \mathrm{~b}$ & $78.13 \pm 5.01 \mathrm{~b}$ \\
Autumn dry season & $10.96 \pm 0.60 \mathrm{~b}$ & $75.51 \pm 5.34 \mathrm{~b}$ \\
\hline
\end{tabular}

Means with the same letters in a column are statistically equal $(\mathrm{P} \leq$ $0.05)$.

\section{Distilled "ordinary" and "white" alcohol production}

The volume of the "ordinary" alcohol obtained from the juice of cooked "piñas" varied $(\mathrm{P} \leq 0.05)$ among plant ages (Table 5). The 19 years-old "piñas" produced as much as $159 \mathrm{~mL}$ of ordinary alcohol, whereas the 8 years-old plants produced only $28 \mathrm{~mL}$ per liter of juice. A similar pattern was obtained for the "white" alcohol production also; the 19 years-old "piñas" produced as much as $108.1 \mathrm{~mL}$ of "white" alcohol per liter of "ordinary" alcohol, while the 8 years-old plants produced $56.8 \mathrm{~mL}$ per liter.

Regarding the effect of climatic conditions on the production of both "ordinary" and "white" alcohols, the early autumn rainy season harvest rendered the highest values for "ordinary" alcohol (114 mL per liter of juice) whereas and the summer rainy period showed the lowest with $49.3 \mathrm{~mL}$ per liter of juice (Table 6). For "white" alcohol production, the best season was the spring dry season harvest with $138 \mathrm{~mL}$ per liter, and the lowest volume (14.0 $\mathrm{mL}$ per liter) was attained in the early autumn dry season.

The ethanol contents in the "ordinary" and "white" alcohols collected were not affected $(\mathrm{P} \leq 0.05)$ by plant age, although the 5 years-old "piñas" rendered from 15 to $35 \%$ more ethanol than older "piñas" (Table 5). The climatic conditions prior to harvest had a significant effect $(\mathrm{P} \leq 0.05)$ on the ethanol content. The spring dry season harvest showed ethanol contents of $282.5 \mathrm{~g} \mathrm{~L}^{-1}$ of "ordinary" alcohol and $524.5 \mathrm{~g} \mathrm{~L}^{-1}$ of "white" alcohol (Table 6). The lowest values were obtained from "piñas" harvested in the autumn dry season with $131.7 \mathrm{~g}$ of ethanol per liter of "ordinary" alcohol and $251.2 \mathrm{~g}$ of ethanol per liter of "white" alcohol (Table 5).

Table 5. Distilled "ordinary" and redistilled "white" alcoholic production yield of fermented juice of henequen "piñas" of different ages. Ethanol content in both distillations is shown. $(n=9 \pm$ standard deviation).

\begin{tabular}{lcccc}
\hline $\begin{array}{l}\text { Plant age } \\
\text { (years) }\end{array}$ & $\begin{array}{c}\text { Distilled "ordinary" production } \\
\text { (mL L-1 juice) }\end{array}$ & $\begin{array}{c}\text { Ethanol content } \\
\left(\mathrm{g} \mathrm{L}^{-1}\right)\end{array}$ & $\begin{array}{c}\text { Redistilled "white" production } \\
\left(\mathrm{mL} \mathrm{L}^{-1} \text { "ordinary" distilled }\right)\end{array}$ & $\begin{array}{c}\text { Ethanol content } \\
\left(\mathrm{g} \mathrm{L}^{-1}\right)\end{array}$ \\
\hline 5 & $34.38 \pm 10.14 \mathrm{~b}$ & $230.20 \pm 22.63 \mathrm{a}$ & $66.68 \pm 21.49 \mathrm{~b}$ & $508.52 \pm 82.53 \mathrm{a}$ \\
8 & $27.90 \pm 3.99 \mathrm{~b}$ & $202.90 \pm 35.20 \mathrm{a}$ & $56.85 \pm 15.22 \mathrm{~b}$ & $333.99 \pm 79.56 \mathrm{a}$ \\
15 & $59.78 \pm 15.69 \mathrm{~b}$ & $244.13 \pm 31.69 \mathrm{a}$ & $98.42 \pm 23.51 \mathrm{ab}$ & $370.86 \pm 72.92 \mathrm{a}$ \\
18 & $141.44 \pm 22.36 \mathrm{a}$ & $232.40 \pm 30.00 \mathrm{a}$ & $70.52 \pm 19.57 \mathrm{ab}$ & $405.10 \pm 62.26 \mathrm{a}$ \\
19 & $159.02 \pm 48.28 \mathrm{a}$ & $243.57 \pm 33.80 \mathrm{a}$ & $108.15 \pm 29.52 \mathrm{a}$ & $434.63 \pm 68.61 \mathrm{a}$ \\
\hline
\end{tabular}

Means with the same letters in a column are statistically equal $(\mathrm{P} \leq 0.05)$.

Table 6. Distilled "ordinary" and redistilled "white" alcoholic production of fermented juice from henequen "piñas" harvested in different climatic conditions throughout the year. Ethanol content in both distillations is shown. ( $n=9 \pm$ standard deviation)

\begin{tabular}{lcccc}
\hline $\begin{array}{l}\text { Plant age } \\
\text { (years) }\end{array}$ & $\begin{array}{c}\text { Distilled "ordinary" production } \\
\left(\mathrm{mL} \mathrm{L}^{-1} \text { juice }\right)\end{array}$ & $\begin{array}{c}\text { Ethanol content } \\
\left(\mathrm{g} \mathrm{L}^{-1}\right)\end{array}$ & $\begin{array}{c}\text { Redistilled "white" production } \\
\left(\mathrm{mL} \mathrm{L}^{-1} \text { "ordinary “ distilled }\right)\end{array}$ & $\begin{array}{c}\text { Ethanol content } \\
\left(\mathrm{g} \mathrm{L}^{-1}\right)\end{array}$ \\
\hline Spring dry season & $89.83 \pm 11.7 \mathrm{a}$ & $282.51 \pm 6.48 \mathrm{a}$ & $138.08 \pm 11.20 \mathrm{a}$ & $524.54 \pm 10.09 \mathrm{a}$ \\
Summer rainy season & $49.37 \pm 13.89 \mathrm{~b}$ & $277.62 \pm 5.91 \mathrm{a}$ & $87.88 \pm 15.62 \mathrm{~b}$ & $456.03 \pm 31.39 \mathrm{a}$ \\
Autumn dry season & $114.31 \pm 35.47 \mathrm{a}$ & $131.78 \pm 23.84 \mathrm{~b}$ & $14.45 \pm 4.37 \mathrm{c}$ & $251.29 \pm 77.81 \mathrm{~b}$ \\
\hline
\end{tabular}

Means with the same letters in a column are statistically equal $(\mathrm{P} \leq 0.05)$. 
We postulated that the content of sugars in the stem will be affected by the climate and plant age. Our observations showed that climate has a greater effect on sugars accumulation in the stems ("piñas") of $A$. fourcroydes than plant age. Our observations revealed that age has less effect on the other variables studied than the climatic season of harvest. For instance, the total soluble solids $\left({ }^{\circ}\right.$ Brix $)$ content recorded in "piñas" showed slight differences as the plant aged, whereas "piñas" collected in the dry season regularly had higher values of ${ }^{\circ}$ Brix than those harvested in the rainy seasons, possibly because soil dryness reduced tissue water content so that solutes become more concentrated in the "piña" tissues. In contrast with other cultivated agave species, the henequen "piñas" do not increase in size and weight as in A. tequilana, where the weight of the "piña" increased with age (ValenzuelaZapata, 1985; Nobel, 1994).

It has been proposed and demonstrated that henequen can be cultivated not only for fibers but also for alcohol spirit. The "piña" of henequen, however, differs from those agaves used only for alcoholic spirits, such as tequila and mezcal. In henequen the leaves are constantly harvested for fiber production, thereby reducing the photosynthetic surface, and consequently reducing the production of the sugars used for growth and ultimately stored in the stem, which may be used for further processing such as alcohol production. The removal of at least 25-30 leaves per year during the life of the plant continues for about 20 years and probably affects the amount and quality of the stored sugars since some of then were used for fiber synthesis. Such synthesis should be an interesting research line that might facilitate an understanding of structural carbohydrates metabolism.

However, we found a positive relation between plant age and both TSS and sugar content when these variables are evaluated in the juice of cooked "piñas. Older plants had higher concentrations of soluble solids measured in ${ }^{\circ}$ Brix, than younger plants; similarly, older plants (18 and 19 years) had higher contents of reducing sugars than the younger ones. Other agaves, such as $A$. tequilana, are harvested when the "piñas" have their greatest content of reducing sugars, which regularly occurs when plants are over eight years old, just before flowering (Cedeño and Alvarez-Jacobs, 2000; Valenzuela-Zapata, 1985). In henequen the volume of juice obtained from cooked "piñas" is highest in older plants harvested in the rainy season, a fact that may be caused by the increase in water availability because of rains.

As it was mentioned above, the cooked juice from the "piñas" was fermented and the production of distilled al- cohol spirit measured. In the dry season the older plants yielded a greater volume of "ordinary" or "white" distilled alcohol than the younger plants harvested in the rainy season. Ethanol content in the "ordinary"distilled alcohol varied from 203 to $244 \mathrm{~g} \mathrm{~L}^{-1}$ of juice, values which are close to those recorded for $A$. tequilana (Prado, 2004). Here again the age of the plant did not affect the ethanol content of the "ordinary" distilled alcohol; however, this content was affected by the climatic conditions, particularly when water was available in the environment during the autumn dry season. The highest values of ethanol in "white" distilled alcohol were found in the spring dry season (508 g per liter of "ordinary" alcohol equivalent to $63 \%$ of the volume), at any age of the plant. The smallest white alcohol values (200 to $400 \mathrm{~g} \mathrm{~L}^{-1}$ ) were found in the "piñas" harvested in any the two summer rainy seasons or autumn dry season (Summer and Autumn). Our data indicates that 1.6 to $3.9 \mathrm{~kg}$ of "piña" are needed to produce one liter of juice which in turn produces from 90 to $114 \mathrm{~mL}$ of alcohol after fermentation.

Our observations suggest that the nonstructural carbohydrates produced by $A$. fourcroydes and stored in their stems, can be fermented to produce an alcoholic spirit, in addition to the agronomical use, thereby increasing the economical importance of this plant for the sustainable agriculture in Yucatán, México.

We concluded that climate has a greater effect on sugars accumulation in the stems (piñas) of $A$. fourcroydes than plant age. However, both the total soluble solids and the sugars contents in the juice of cooked "piñas" increased with plant age, since older plants had higher concentrations of soluble solids (measured in ${ }^{\circ}$ Brix), than younger plants.

Juice from cooked "piñas" of older plants yield greater volumens of "ordinary" or "white" distilled alcohol than younger plants harvested in the rainy seasons. The dry spring periods of the year favor the accumulation of sugars; hence more alcohol may be produced in this season than in any of the other two rainy seasons tested. In fact, henequen plants over 15 years old produce larger amounts of alcohol compared to younger plants.

\section{ACKNOWLEDGEMENTS}

To CONACyT (grant 17037) for the economic support to carry out the present research work and the doctoral studies formation of the first author, and to Silvia Vergara Yoisura for helping with the of the manuscript preparation. 


\section{BIBLIOGRAPHY}

Aspinall G O, P C Gupta (1959) The structure of the fructosan from Agave veracruz Mill. J. Am. Chem. Soc. 81:718-722.

Ayora-Cámara M E (1986) Determinación de las principales características físicas y químicas del jugo fresco de henequén (Agave fourcroydes). Gestión Tecnológica 4:7-12.

Cedeño M C, J Alvarez-Jacobs (2000) Tequila Production from Agave. In: Murtagh \& Associates (ed). The Alcohol Textbook. 3rd ed. Nottingham University Press. pp:223-243.

Duch G J (1988) La Conformación Territorial del Estado de Yucatán. Universidad Autónoma de Chapingo. Estado de México. México. $180 \mathrm{p}$.

Duch G J (1991) Fisiografía del Estado de Yucatán, su Relación con la Agricultura. Universidad Autónoma de Chapingo. Estado de México. México. 223 p.

Gómez-Ayala R C, C Jacques, J A Ramírez-de León (2004) Extracción de la inulina y azúcares del agave con métodos químicos. Revista Salud Pública y Nutrición (RESPYN) No. 1. Ed. Especial. Disponible en: www.uanl.mx/publicaciones/respyn/ especiales/ee-1-2005/51.htlm (Diciembre de 2006).

Guerrero M R, E R Dzib (1983) Guía para el Cultivo del Henequén en Plantación Definitiva. Folleto para Productores No. 7. INIACIAPY. Mérida, Yucatán, México. 16 p.

López M G, N A Mancilla-Margalli, G Mendoza-Díaz (2003) Molecular structures of fructans from Agave tequilana Weber var. azul. J. Agric. Food Chem. 51:7835-7840.
Nobel P S (1985) PAR, water and temperature limitations on the productivity of cultivated Agave fourcroydes (henequen). J. Appl. Ecol. 22:157-173.

Nobel P S (1994) Remarkable Agaves and Cacti. Cambridge University Press. New York. $166 \mathrm{p}$

Nobel P S, M Castañeda, G North, E Pimienta-Barrios, A Ruiz (1998) Temperature influences on leaf $\mathrm{CO}_{2}$ exchange, cell viability and cultivation range for Agave tequilana. J. Arid Environ. 39:1-9.

Pimienta-Barrios E, C Robles-Murguía, P S Nobel (2001) $\mathrm{Net}^{\mathrm{CO}_{2}}$ uptake for Agave tequilana in a warm and a temperate environment. Biotropica 33:312-318.

Prado R R (2004) Destilación. In: Ciencia y Tecnología del Tequila, Avances y Perspectivas. CIATEJ. Guadalajara, Jalisco, México. pp:123-168.

Ramales-Osorio M C, M L Barragán-Rámirez (2002) La industria del mezcal y la economía oaxaqueña. Observatorio de la Economía Latinoamericana. Disponible en: http://www.eumed.net/ cursecon/ecolat $/ \mathrm{mx} /$ (Diciembre de 2006).

Tello-Balderas J J, E García-Moya (1985) The mezcal industry in the altiplano potosino-zacatecano of north-central Mexico. Desert Plant 7:81-88

Valenzuela-Zapata A G (1985) The tequila industry in Jalisco, Mexico. Desert Plant 7:65-70.

Wang N, P S Nobel (1998) Phloem transport of fructans in the crassulacean acid metabolism species Agave deserti. Plant Physiol. 116:709-714. 